\title{
Excipient:Drug Dose Determination for Neointimal Hyperplasia as Assessed by Optical Coherence Tomography and Histopathology in Porcine Coronary Arteries after Sirolimus-Eluting Balloon Employment
}

\author{
Celso Kiyochi Takimura ${ }^{1}$, Micheli Zanotti Galon², Prakash Sojitra ${ }^{3}$, Manish Doshi ${ }^{4}$, Vera Aiello $^{5}$, \\ Paulo Sampaio Gutierrez ${ }^{6}$, Juliana Carvalho ${ }^{7}$, Suzane Kiss Ferreira ${ }^{8}$, Marcio Jose Figueira Chaves ${ }^{9}$, \\ Francisco Rafael Martins Laurindo ${ }^{10}$, Pedro Alves Lemos ${ }^{11}$
}

\begin{abstract}
Background: Magic Touch ${ }^{\mathrm{TM}}$ is a sirolimus-based nano-carrier eluting balloon. This study aimed to find the excipient:drug ratio with the greatest capacity to inhibit neointimal proliferation 28 days after the use of this balloon and following bare-metal stenting in porcine coronary arteries. Methods: Fourteen domestic pigs who received coronary bare-metal stent implants followed by dilation ( 60 seconds) using balloons with excipient:sirolimus ratios of $1: 1,0.5: 1,0.25: 1$, and $1: 0$ or a control balloon were evaluated. After 28 days, neointimal hyperplasia was assessed by optical coherence tomography and histopathology. Results: The rate of neointimal hyperplasia as assessed by optical coherence tomography and histomorphometry was $32.2 \%$ and $35.1 \%, 28.1 \%$ and $33.4 \%, 17.3 \%$ and $20.9 \%, 28.6 \%$ and $30.2 \%$, and $37.9 \%$ and $42.3 \%$ in the $0.25: 1,0.5: 1,1: 1$, and 1:0 excipient:sirolimus ratio groups and the control balloon group, respectively $(\mathrm{P}=0.03$ for excipient:sirolimus $1: 1$ versus control balloon). The neointimal interstrut thickness $(\mathrm{mm})$ was $0.23,0.30,0.16,0.24$, and 0.30 in the $0.25: 1,0.5: 1,1: 1$, and 1:0 excipient:sirolimus ratio groups and the control balloon group, respectively $(\mathrm{P}<0.01$ for excipient:sirolimus 1:1 versus control balloon). The inflammation, injury, and fibrin deposition scores were low, and there were no significant differences among the groups. Conclusions: There was a stepwise increase in the inhibitory efficacy of neointimal proliferation as the excipient concentration increased. The lowest efficacy was observed with the $0.25: 1$ excipient:sirolimus formulation, and the greatest inhibition was observed with the 1:1
\end{abstract}

RESUMO

Estudo da Dose Excipiente:Fármaco com Avaliação da Hiperplasia Neointimal por Tomografia de Coerência Óptica e Histopatologia em Artérias Coronárias Porcinas após o Emprego do Balão Eluidor de Sirolimus

Introdução: Magic TouchTM é um balão recoberto com nanopartículas carreadoras de sirolimus. Objetivamos encontrar a dose excipiente:fármaco com a maior capacidade de inibição da proliferação neointimal 28 dias após o uso desse balão pós-implante de stent não farmacológico em artérias coronárias porcinas. Métodos: Foram avaliados 14 porcos com implante coronário de stent não farmacológico seguido por dilatação (60 segundos) com balões com relação excipiente:sirolimus $1: 1,0,5: 1,0,25: 1$ e 1:0 ou balão controle. Após 28 dias a hiperplasia neointimal foi estudada por tomografia de coerência óptica e histopatologia. Resultados: A hiperplasia neointimal porcentual (\%) avaliada pela tomografia de coerência óptica e pela histomorfometria foi de 32,2 e 35,1, 28,1 e 33,4, 17,3 e 20,9, 28,6 e 30,2, e 37,9 e 42,3 nos grupos excipiente:sirolimus $0,25: 1,0,5: 1,1: 1,1: 0$ e balão controle, respectivamente ( $P=0,03$ para excipiente:sirolimus 1:1 vs. balão controle). A espessura $(\mathrm{mm})$ da neoíntima inter-hastes foi de 0,23, 0,30, $0,16,0,24$ e 0,30 nos grupos excipiente:sirolimus $0,25: 1$, $0,5: 1,1: 1,1: 0$ e balão controle, respectivamente $(\mathrm{P}<0,01$ para excipiente:sirolimus 1:1 vs. balão controle). Os escores de inflamação, injúria e deposição de fibrina foram baixos e sem diferenças significantes entre os grupos. Conclusões: Ocorreu
$1 \mathrm{PhD}$ in Sciences. Researcher Physician at the Instituto do Coração do Hospital das Clínicas da Faculdade de Medicina da Universidade de São Paulo. São Paulo, SP, Brazil.

${ }^{2}$ Cardiologist at the Instituto do Coração do Hospital das Clínicas da Faculdade de Medicina da Universidade de São Paulo. São Paulo, SP, Brazil.

${ }^{3}$ Engineer at Concept Medical Research Private Limited. Cleveland, Ohio, USA.

${ }^{4}$ Engineer at Concept Medical Research Private Limited. Cleveland, Ohio, USA.

${ }^{5}$ Tenured Professor. Physician at the Instituto do Coração do Hospital das Clínicas da Faculdade de Medicina da Universidade de São Paulo. São Paulo, SP, Brazil.

${ }^{6}$ Tenured Professor. Physician at the Instituto do Coração do Hospital das Clínicas da Faculdade de Medicina da Universidade de São Paulo. São Paulo, SP, Brazil.
${ }^{7}$ Biologist at the Instituto do Coração do Hospital das Clínicas da Faculdade de Medicina da Universidade de São Paulo. São Paulo, SP, Brazil. ${ }^{8}$ Biologist at the Instituto do Coração do Hospital das Clínicas da Faculdade de Medicina da Universidade de São Paulo. São Paulo, SP, Brazil. ${ }^{9}$ Biologist at the Instituto do Coração do Hospital das Clínicas da Faculdade de Medicina da Universidade de São Paulo. São Paulo, SP, Brazil. 10 Tenured Professor. Physician at the Instituto do Coração do Hospital das Clínicas da Faculdade de Medicina da Universidade de São Paulo. São Paulo, SP, Brazil.

${ }^{11}$ Tenured Professor. Physician at the Instituto do Coração do Hospital das Clínicas da Faculdade de Medicina da Universidade de São Paulo. São Paulo, SP, Brazil.

Correspondence to: Celso Kiyochi Takimura. Rua Botelho, 155/162 Vila Guarani - São Paulo, SP, Brazil - CEP 04313-200

E-mail: celsotakimura@hotmail.com

Received on: 3/21/2012 • Accepted on: 5/30/2012 
excipient:sirolimus formulation. The 1:1 excipient:sirolimus formulation significantly reduced neointimal proliferation when compared to the control group, with low inflammation and injury scores.

DESCRIPTORS: Angioplasty, balloon, coronary. Coronary restenosis. Stents. Sirolimus. Animal studies.

D rugs with antiproliferative properties, such as paclitaxel and drugs from the 'limus' family (sirolimus, everolimus, zotarolimus, biolimus A9, and amphilimus), are embedded in metallic stents, ${ }^{1-5}$ in bioabsorbable stents, ${ }^{6}$ and also in drug-eluting balloons. ${ }^{7}$

Restenosis after vascular intervention persists, despite the enormous advances made with the introduction of drug-eluting stents (DES). However, possibly as an effect of the retardation of stent endothelialisation and of the inflammatory effects arising from the presence of the polymers that carry the antiproliferative drugs, these DES have directed attention towards previously little known entities, such as stent thrombosis. ${ }^{8}$ Metal stents, both drug-eluting and non-eluting, have several limitations, such as their use in lesions in very small-diameter vessels, long lesions, or at very distal locations, as well as in lesions with pronounced proximal curvature. For these cases, alternatives are required.

Part of the solution may be the use of drug-eluting bioabsorbable stents, which provide temporary support for the vascular wall, minimising the elastic retraction and repairing the dissection that occurs with lesion dilation, resulting in a significant reduction in neointimal proliferation when combined with antiproliferative drugs. ${ }^{9}$

Drug-eluting balloons are a possible alternative for metallic stent adjunct therapy. Several paclitaxeleluting balloons are already commercially available. These paclitaxel-eluting balloons have been shown to be safe and effective in preclinical and clinical studies and are especially effective in the treatment of intrastent coronary restenosis. ${ }^{10}$ Clinical studies are being performed to evaluate paclitaxel-eluting balloon efficacy in treating other coronary lesions, such as those located in small-calibre vessels, in chronic occlusions or accompanying clinical conditions such as diabetes mellitus and acute myocardial infarction.

Sirolimus, similar to paclitaxel and zotarolimus, is a drug with lipophilic behaviour and is thus ideal for incorporation on the surface of these drug-eluting balloons. Furthermore, it is a well-known drug and has been well-characterised since 1996, when its clinical use as an adjuvant therapy after renal transplantation was initiated. ${ }^{11}$ It was used in the first commercially gradual aumento da eficácia inibitória da proliferação neointimal à medida que a concentração do excipiente aumentou; a menor eficácia ocorreu com a formulação excipiente:sirolimus 0,25:1 e a mais intensa inibição foi observada com a formulação excipiente:sirolimus $1: 1$, a qual reduziu significantemente a proliferação neointimal em comparação com o grupo controle, com baixos índices de inflamação e injúria.

DESCRITORES: Angioplastia coronária com balão. Reestenose coronária. Stents. Sirolimo. Experimentação animal.

available drug-eluting stent $\left(\right.$ Cypher $^{\circledR}$, Cordis Corp. - Warren, NJ, USA) ${ }^{12}$ and was the first drug used to coat the DES manufactured in Latin America (Inspiron ${ }^{\circledR}$, Scitech Medical - Goiânia, GO, Brazil). ${ }^{1}$

The aim of this study was to find the best excipient:drug ratio of a sirolimus-based nano-carrier balloon (Magic Touch $^{\text {TM }}$, Concept Medical, Inc. - Cleveland, OH, USA) without polymer coating for use after bare-metal stent implantation in porcine coronary arteries.

\section{METHODS}

\section{Ethical aspects}

All procedures were planned and performed in compliance with the standards of protection and care for laboratory animals established in the Ethical Principles in Animal Experimentation of the Research and Animal Experimentation Support Service of the Instituto do Coração, Faculdade de Medicina, Universidade de São Paulo, Brazil, as well as in the Guide for the Care and Use of Laboratory Animals (Institute of Laboratory Animal Resources, Commission on Life Sciences and National Research Council, National Academy Press, Washington, DC, 1996), and the Ethical Principles in Animal Experimentation of the Colégio Brasileiro de Experimentação Animal (Brazilian College of Animal Experimentation, COBEA). ${ }^{13}$

\section{Animal model}

A total of 14 young domestic female, nonatherosclerotic pigs from a commercial farm received intramuscular premedication (ketamine $3 \mathrm{mg} / \mathrm{kg}$, and midazolam $0.5 \mathrm{mg} / \mathrm{kg}$ ) followed by intravenous infusion of thiopental, endotracheal intubation, and mechanical ventilation with maintenance of anaesthesia with isoflurane. Oxygen saturation was monitored through the animal's tail, and heart rate and rhythm were monitored with a cardiac monitor. ${ }^{14}$

\section{Technical information on nano-carrier balloons}

Nanoparticles consisting of a phospholipid bilayer and different excipient:sirolimus formulations were prepared: $0.25: 1,0.5: 1,1: 1$, and 1:0. These nanoparticles 
had a mean diameter of 210 nanometres and were applied to the surface of coronary angioplasty balloons via a conventional spray technique assisted by inert gas. In vitro tests indicated stable coating adhesion to the balloons, as well as smooth, regular, uniform surfaces without folds or fractures. ${ }^{15,16}$ These nanoparticles, when applied to coronary angioplasty balloons after a brief exposure of 60 seconds in the arterial wall, are initially found on the endothelial surface, then on the middle layer, and finally, at deeper locations in the adventitial wall. ${ }^{17}$

\section{Operative technique}

After dissection of the common femoral artery, a 6-F introducer sheath was inserted under direct vision, and 10,000 IU of unfractionated heparin were administered. Then, a 6-F Judkins right therapeutic catheter was introduced (Philips - Eindhoven, the Netherlands) and monitored by fluoroscopy via Philips BV Pulsera digital angiography equipment (Philips - Eindhoven, the Netherlands). Each coronary artery was selectively catheterised, and $200 \mu \mathrm{g}$ of intracoronary nitroglycerine were administered. The angiographic projection of choice for both the left and right coronary arteries was the left anterior oblique at 60 degrees.

After intracoronary passage of a 0.014-inch guidewire, cobalt-chromium bare-metal stents (Cronus ${ }^{\text {TM }}$, Scitech - Goiânia, GO, Brazil) were implanted according to an expanded balloon diameter:artery ratio of 1.1:1. The animals, according to previous randomisation, were selected to receive one stent per artery and a drug-eluting balloon (four different formulations) or a conventional balloon per stent. Thus, the 14 animals underwent 35 treatments (seven balloons with a 0.25:1 formulation, seven balloons with a 0.5:1 formulation, seven balloons with a 1:1 formulation, seven balloons with a 1:0 formulation, and seven conventional balloons). Each stent was dilated for 60 seconds with a balloon coated with nanoparticles or with the same balloon used for stent release (control group).

After the procedure, the animals were taken to pens where they received water ad libitum, commercial feed, and antiplatelet agents (aspirin $100 \mathrm{mg}$ and clopidogrel $75 \mathrm{mg}$ ) daily for 28 days, when they were returned to the lab to be submitted again to coronary angiography, optical coherence CT, and subsequently, euthanasia.

\section{Coronary angiography control}

After the administration of pre-anaesthetic medication, intubation, inhalation anaesthesia, and the administration of intracoronary nitroglycerine, control coronary angiographies were performed using the same projection used in the index angiographic procedure.

\section{Optical coherence tomography}

Immediately after the control coronary angiography, optical coherence tomography images were obtained using an M2 OCT system (LightLab Imaging - Westford, MA, USA).

Initially, a 0.014-inch guidewire was passed through the coronary artery distal to the treated site. Then, a Helios ${ }^{\circledR}$ balloon (LightLab Imaging) with high compliance was introduced over the guide and positioned distally to the treated site. Then, the 0.014-inch guidewire was retreated proximally, and exchanged for an ImageWire ${ }^{\circledR}$ catheter (LightLab Imaging). The Helios $^{\circledR}$ balloon was retreated proximally, and insufflated with an equivolumetric mixture of saline solution and contrast until blood flow occlusion occurred. At that moment, saline solution was infused to wash the intravascular blood and to obtain optical coherence tomography images, followed by an automated retreat of the optical coherence tomography image catheter at $1 \mathrm{~mm} / \mathrm{second}$. These images were analysed to determine the presence of thrombus, strut malposition, and tissue-covering struts, and semiautomated measurements were performed of the lumen area, the stent area, and the neointimal thickness (distance from stent struts to the lumen). The neointimal area (stent area minus the lumen area) and the percentage of neointimal percentage neointimal area (neointimal area divided by the stent area and then multiplied by 100) were calculated.

After the optical coherence tomography images were obtained, the animals received an additional dose of anaesthetic medication, followed by a lethal dose of potassium chloride.

After euthanasia, paramedian left thoracotomy and pericardiotomy were performed, and the vena cava, the pulmonary trunk and the aorta were carefully clamped and sectioned, and the heart was removed. The heart was then washed with water, and a $10 \%$ formaldehyde solution was infused under a pressure of $100 \mathrm{mmHg}$ at the aortic root for coronary perfusion for 30 minutes. The arterial segments containing stents were dissected, removed, and placed in a $10 \%$ formaldehyde solution and sent for histological analysis, as described in a previous study..$^{18}$

\section{Histopathology}

Three histological cuts were performed per stent segment (proximal, middle, and distal). These sections were stained with haematoxylin-eosin, using a Verhoeff stain for elastic fibres, and subsequently qualitatively and quantitatively analysed by specialised pathologists and a technician blinded to the treatment on each slide. For the quantitative analysis, the modified inflammation scores of Kornovski, ${ }^{19}$ the fibrin score, ${ }^{20}$ and the injury scores of Schwartz ${ }^{21}$ and Gunn were used. ${ }^{22}$ 
The measurements of the lumen area, stent area, internal elastic lamina area, external elastic lamina area, and neointimal thickness on the struts and interstrut thickness were performed using Leica Qwin software (Leica Microsystems - Wetzlan, Germany).

\section{Statistical analysis}

Data are presented as median (minimum-maximum) or percentages (\%) (minimum-maximum). One-way analysis of variance (ANOVA) was used for comparison between groups, and post hoc analysis if the variance ratio test (F test) was significant. The Statistical Package for Social Sciences (SPSS), version 13, was used for data analysis, and a $\mathrm{P} \leq 0.05$ was considered statistically significant.

\section{RESULTS}

The 14 animals survived the index procedure up to 28 days post-treatment.

During the control angiography, it was observed that all coronary arteries were patent and had no images suggestive of dissection, thrombus, or aneurysm.

\section{Optical coherence tomography}

All stents presented complete tissue coating, and there were no cases of stent strut malposition.

The implanted stents that were dilated with a sirolimuseluting balloon with an excipient:sirolimus formulation of 1:1 presented lower neointimal area, lower neointimal area percentage, and lower neointimal thickness, when compared with the control balloon group $\left(1.46 \mathrm{~mm}^{2} \mathrm{vs}\right.$. $2.16 \mathrm{~mm}^{2}, 17.3 \%$ vs. $32.2 \%$, and $0.15 \mathrm{~mm}$ vs. $0.31 \mathrm{~mm}$, respectively) $(\mathrm{P}=0.03)$ (Table 1$)$.

\section{Histopathology}

\section{Histomorphometric findings}

Stents that were dilated with an excipient:sirolimus 1:1 formulation presented lower neointimal area, lower neointimal area percentage, lower neointimal thickness on the struts, and lower neointimal interstrut thickness as compared to the control balloon group (Table 2).

\section{Histomorphological findings}

Low inflammation and fibrin scores were observed in all groups, with no significant differences among them.

The injury scores (Schwartz and Gunn) were similar in all groups, with no significant differences (Table 3).

\section{DISCUSSION}

In 2000, Herdeg et al. ${ }^{23}$ demonstrated that after angioplasty in the carotid arteries of rabbits, local administration of paclitaxel resulted in a reduction of neointimal proliferation area. This resulted in the conception and subsequent development of a new class of devices used for percutaneous vascular therapy: the drug-eluting balloons.

Scheller et al., ${ }^{24}$ in preclinical studies, extensively evaluated paclitaxel-coated balloons and observed in a clinical study a decrease in the neointimal proliferation and efficacy in the treatment of intrastent restenosis. ${ }^{25}$

In drug-eluting stents, only $15 \%$ of the vessel surface is in contact with the stent struts, and drugeluting balloons have the potential advantage of allowing antiproliferative drug delivery to the arterial

TABLE 1

Quantitative Findings of Optical Coherence Tomography

\begin{tabular}{|c|c|c|c|c|c|c|}
\hline & $\begin{array}{c}\text { Excipient:sirolimus } \\
\begin{array}{c}0.25: 1 \\
(n=7)\end{array}\end{array}$ & $\begin{array}{c}\text { Excipient:sirolimus } \\
0.5: 1 \\
(\mathbf{n}=7)\end{array}$ & $\begin{array}{l}\text { Excipient:sirolimus } \\
\begin{array}{c}1: 1 \\
(n=7)\end{array}\end{array}$ & $\begin{array}{c}\text { Excipient:sirolimus } \\
\begin{array}{c}\mathbf{1 : 0} \\
(\mathbf{n}=7)\end{array}\end{array}$ & $\begin{array}{l}\text { Control } \\
\text { balloon } \\
(n=7)\end{array}$ & $\mathbf{P}$ \\
\hline Stent, $\mathrm{mm}^{2}$ & $\begin{array}{c}7.62 \\
(6.53-8.69)\end{array}$ & $\begin{array}{c}9.36 \\
(8.25-11.17)\end{array}$ & $\begin{array}{c}7.95 \\
(7.23-11.26)\end{array}$ & $\begin{array}{c}8.15 \\
(6.74-8.64)\end{array}$ & $\begin{array}{c}7.89 \\
(7.33-9.47)\end{array}$ & 0.4 \\
\hline Lumen, $\mathrm{mm}^{2}$ & $\begin{array}{c}4.43 \\
(3.65-5.83)\end{array}$ & $\begin{array}{c}6.61 \\
(3.59-9.42)\end{array}$ & $\begin{array}{c}5.96 \\
(5.89-9.71)\end{array}$ & $\begin{array}{c}6.02 \\
(3.04-6.52)\end{array}$ & $\begin{array}{c}4.36 \\
(3.12-6.22)\end{array}$ & 0.5 \\
\hline $\begin{array}{l}\text { Neointimal } \\
\text { area, } \mathrm{mm}^{2}\end{array}$ & $\begin{array}{c}2.16 \\
(2.01-3.85)\end{array}$ & $\begin{array}{c}2.76 \\
(1.57-4.49)\end{array}$ & $\begin{array}{c}1.46 \\
(0.98-2.22)\end{array}$ & $\begin{array}{c}2.27 \\
(1.81-3.62)\end{array}$ & $\begin{array}{c}2.44 \\
(1.78-3.70)\end{array}$ & $0.03 *$ \\
\hline $\begin{array}{l}\text { Neointimal } \\
\text { area } \\
\text { percentage, \% }\end{array}$ & $\begin{array}{c}32.2 \\
(26.6-51.3)\end{array}$ & $\begin{array}{c}28.1 \\
(14.1-66.2)\end{array}$ & $\begin{array}{c}17.3 \\
(12.2-25.1)\end{array}$ & $\begin{array}{c}28.6 \\
(21.7-52.7)\end{array}$ & $\begin{array}{c}37.9 \\
(26.6-48.6)\end{array}$ & $0.03 *$ \\
\hline $\begin{array}{l}\text { Neointimal } \\
\text { thickness, mm }\end{array}$ & $\begin{array}{c}0.27 \\
(0.24-0.49)\end{array}$ & $\begin{array}{c}0.24 \\
(0.19-0.67)\end{array}$ & $\begin{array}{c}0.15 \\
(0.12-0.21)\end{array}$ & $\begin{array}{c}0.27 \\
(0.23-0.48)\end{array}$ & $\begin{array}{c}0.31 \\
(0.25-0.53)\end{array}$ & $0.03 *$ \\
\hline
\end{tabular}

* Comparison, excipient:sirolimus 1:1 vs. control balloon. 
TABLE 2

Histomorphometric Findings

\begin{tabular}{|c|c|c|c|c|c|c|}
\hline & $\begin{array}{l}\text { Excipient:sirolimus } \\
\begin{array}{c}0.25: 1 \\
(n=7)\end{array}\end{array}$ & $\begin{array}{c}\text { Excipient:sirolimus } \\
\begin{array}{c}0.5: 1 \\
(n=7)\end{array}\end{array}$ & $\begin{array}{c}\text { Excipient:sirolimus } \\
\begin{array}{c}1: 1 \\
(\mathbf{n}=7)\end{array}\end{array}$ & $\begin{array}{c}\text { Excipient:sirolimus } \\
\begin{array}{c}1: 0 \\
(\mathbf{n}=7)\end{array}\end{array}$ & $\begin{array}{l}\text { Control } \\
\text { balloon } \\
(n=7)\end{array}$ & $\mathbf{P}$ \\
\hline $\begin{array}{l}\text { Lumen area, } \\
\mathrm{mm}^{2}\end{array}$ & $\begin{array}{c}3.87 \\
(2.10-4.30)\end{array}$ & $\begin{array}{c}3.78 \\
(1.71-5.74)\end{array}$ & $\begin{array}{c}4.30 \\
(3.19-6.25)\end{array}$ & $\begin{array}{c}3.16 \\
(1.98-4.01)\end{array}$ & $\begin{array}{c}3.37 \\
(2.32-4.45)\end{array}$ & 0.7 \\
\hline $\begin{array}{l}\text { External } \\
\text { elastic } \\
\text { lamina, } \mathrm{mm}^{2}\end{array}$ & $\begin{array}{c}6.57 \\
(4.81-6.99)\end{array}$ & $\begin{array}{c}7.88 \\
(6.47-9.27)\end{array}$ & $\begin{array}{c}6.97 \\
(4.95-8.91)\end{array}$ & $\begin{array}{c}6.11 \\
(4.99-6.79)\end{array}$ & $\begin{array}{c}6.94 \\
(5.70-8.58)\end{array}$ & 0.7 \\
\hline $\begin{array}{l}\text { Internal elastic } \\
\text { lamina, } \mathrm{mm}^{2}\end{array}$ & $\begin{array}{c}5.37 \\
(3.99-5.86)\end{array}$ & $\begin{array}{c}6.23 \\
(5.42-7.91)\end{array}$ & $\begin{array}{c}5.55 \\
(4.01-7.69)\end{array}$ & $\begin{array}{c}5.01 \\
(3.95-5.58)\end{array}$ & $\begin{array}{c}5.49 \\
(4.62-6.46)\end{array}$ & 0.5 \\
\hline $\begin{array}{l}\text { Neointimal } \\
\text { area, } \mathrm{mm}^{2}\end{array}$ & $\begin{array}{c}1.44 \\
(1.18-2.03)\end{array}$ & $\begin{array}{c}2.17 \\
(0.94-4.14)\end{array}$ & $\begin{array}{c}1.22 \\
(0.83-1.35)\end{array}$ & $\begin{array}{c}1.59 \\
(1.12-2.14)\end{array}$ & $\begin{array}{c}1.98 \\
(1.62-2.42)\end{array}$ & $0.02 *$ \\
\hline $\begin{array}{l}\text { Neointimal } \\
\text { percentage } \\
\text { area, \% }\end{array}$ & $\begin{array}{c}35.1 \\
(25.0-58.9)\end{array}$ & $\begin{array}{c}33.4 \\
(27.5-78.6)\end{array}$ & $\begin{array}{c}20.9 \\
(17.4-25.3)\end{array}$ & $\begin{array}{c}30.2 \\
(24.7-54.2)\end{array}$ & $\begin{array}{c}42.3 \\
(34.4-46.1)\end{array}$ & $0.03 *$ \\
\hline $\begin{array}{l}\text { Neointimal } \\
\text { thickness } \\
\text { on struts, mm }\end{array}$ & $\begin{array}{c}0.21 \\
(0.15-0.47)\end{array}$ & $\begin{array}{c}0.28 \\
(0.12-0.75)\end{array}$ & $\begin{array}{c}0.15 \\
(0.13-0.22)\end{array}$ & $\begin{array}{c}0.22 \\
(0.18-0.24)\end{array}$ & $\begin{array}{c}0.28 \\
(0.16-0.45)\end{array}$ & $0.04 *$ \\
\hline $\begin{array}{l}\text { Neointimal } \\
\text { interstrut } \\
\text { thickness, } \\
\text { mm }\end{array}$ & $\begin{array}{c}0.23 \\
(0.18-0.46)\end{array}$ & $\begin{array}{c}0.30 \\
(0.15-0.74)\end{array}$ & $\begin{array}{c}0.16 \\
(0.14-0.21)\end{array}$ & $\begin{array}{c}0.24 \\
(0.21-0.24)\end{array}$ & $\begin{array}{c}0.30 \\
(0.29-0.47)\end{array}$ & $0,01 *$ \\
\hline
\end{tabular}

TABLE 3

Histomorphological Findings

\begin{tabular}{|c|c|c|c|c|c|c|}
\hline & $\begin{array}{c}\text { Excipient:sirolimus } \\
\begin{array}{c}0.25: 1 \\
(\mathbf{n}=7)\end{array}\end{array}$ & $\begin{array}{c}\text { Excipient:sirolimus } \\
0.5: 1 \\
(\mathbf{n}=7)\end{array}$ & $\begin{array}{c}\text { Excipient:sirolimus } \\
\begin{array}{c}1: 1 \\
(\mathbf{n}=7)\end{array}\end{array}$ & $\begin{array}{c}\text { Excipient:sirolimus } \\
\begin{array}{c}\mathbf{1 : 0} \\
(\mathbf{n}=7)\end{array}\end{array}$ & $\begin{array}{l}\text { Control } \\
\text { balloon } \\
(\mathbf{n}=7)\end{array}$ & $\mathbf{P}$ \\
\hline Inflammation & $\begin{array}{c}1 \\
(1-1)\end{array}$ & $\begin{array}{c}1 \\
(1-1)\end{array}$ & $\begin{array}{c}1 \\
(0-1)\end{array}$ & $\begin{array}{c}1 \\
(1-1)\end{array}$ & $\begin{array}{c}1 \\
(1-1)\end{array}$ & $>0.9$ \\
\hline Fibrin & $\begin{array}{c}1 \\
(0-1)\end{array}$ & $\begin{array}{c}1 \\
(0.5-1)\end{array}$ & $\begin{array}{c}1 \\
(0-1)\end{array}$ & $\begin{array}{c}0 \\
(0-0.5)\end{array}$ & $\begin{array}{c}0 \\
(0-1)\end{array}$ & 0.2 \\
\hline $\begin{array}{l}\text { Schwartz } \\
\text { score }\end{array}$ & $\begin{array}{c}1 \\
(0.5-1)\end{array}$ & $\begin{array}{c}1 \\
(1-2)\end{array}$ & $\begin{array}{c}1 \\
(0.5-2)\end{array}$ & $\begin{array}{c}1 \\
(1.5-2)\end{array}$ & $\begin{array}{c}1 \\
(0.5-1)\end{array}$ & 0.7 \\
\hline Gunn score & $\begin{array}{c}2 \\
(2-2)\end{array}$ & $\begin{array}{c}2 \\
(1.5-3)\end{array}$ & $\begin{array}{c}1.5 \\
(1.5-2)\end{array}$ & $\begin{array}{c}2 \\
(1-2.5)\end{array}$ & $\begin{array}{c}1.5 \\
(1.5-2)\end{array}$ & 0.3 \\
\hline
\end{tabular}

wall in a broader and more homogeneous manner. ${ }^{26}$ Other advantages relative to the bare-metal stents are immediate drug release without the use of polymers; a potential reduction in the use of antiplatelet agents; and the ability to be used in lesions in which stent use is not desirable, such as long or distal lesions, segments proximal to the lesion that are too angulated, small-vessel lesions, bifurcation lesions, lesions in peripheral arteries (superficial femoral arteries, popliteal arteries, and other infrapopliteal arteries), and haemodialysis shunts. Potentially, these drug-eluting balloons can also be used in intravascular lesions in paediatric patients. In short, the potential human use of drug-eluting balloons will mainly be for all cases 
where a stent has limitations or when it is not physically desirable.

The European Society of Cardiology (ESC) and the European Association for Cardio-thoracic Surgery (EACTS) recommend the use of paclitaxel-eluting balloons for the treatment of intrastent restenosis, and classified them as a class Ila recommendation with a $\mathrm{B}$ level of evidence. ${ }^{27}$

Nanotechnology applied to the medical area is present in daily practice in materials, equipment, and drugs. The encapsulation of drugs through nanoparticles allows for the application of several drugs to the surface of balloons and stents and, through them, their delivery to tissues. ${ }^{28}$

The present experimental study demonstrated that a balloon covered in sirolimus-eluting nanoparticles used after implantation of bare metal stents was safe, presenting no evidence of local toxic or thrombotic reaction, and that a excipient:drug formulation of $1: 1$ significantly inhibited neointimal proliferation in porcine coronary arteries.

Clinical studies are necessary to evaluate the safety and efficacy in humans and the precise indications for sirolimus-eluting balloons in vascular coronary and peripheral interventions.

This experimental study was limited by the use of animals without atherosclerotic lesions. However, for product development purposes, the use of animals with normal arteries is accepted and recommended by organisations such as the Food and Drug Administration (FDA) ${ }^{29}$

Recently published preclinical studies with zotarolimus-releasing balloons ${ }^{30,31}$ have indicated that the 'limus' family of drugs are promising as antiproliferative agents when applied to medical devices.

\section{CONCLUSIONS}

In this preclinical experiment using a sirolimus-eluting balloon after stent implantation in porcine coronary arteries, a gradual increase in the neointimal proliferation inhibitory efficacy of balloon catheters was observed when increasing excipient:sirolimus ratios were used. The lowest efficacy occurred with an excipient:sirolimus formulation of $0.25: 1$, and the highest occurred with an excipient:sirolimus formulation of $1: 1$, which significantly reduced neointimal proliferation when compared with the control group. These results were accompanied by low levels of inflammation and injury.

\section{CONFLICTS OF INTEREST}

Prakash Sojitra and Manish Doshi are researchers at Concept Medical Research Private Pvt. (Cleveland, $\mathrm{OH}$, USA). The other authors declare no conflicts of interest.

\section{REFERENCES}

1. Ribeiro H, Campos C, Lopes A, Esper R, Abizaid A, Meireles G, et al. Randomized comparison of the efficacy and safety of a novel DES with biodegradable polymer and cobaltchromium alloy - INSPIRON I trial. Eurolntervention. 2011;7 Suppl M:184.

2. Waksman R, Barbash IM, Dvir D, Torguson R, Ben-Dor I, Maluenda G, et al. Safety and efficacy of the Xience V everolimus-eluting stent compared to first-generation drugeluting stents in contemporary clinical practice. Am J Cardiol. 2012;109(9):1288-94.

3. Leon MB, Mauri M, Popma JJ, Cutlip DE, Nikolsky E, O'Shaughnessy $\mathrm{C}$, et al. A randomized comparison of the Endeavor zotarolimus-eluting stent versus the Taxus paclitaxeleluting stent in de novo native coronary lesions. 12-month outcomes from the ENDEAVOR IV Trial. J Am Coll Cardiol. 2010;55(6):543-54.

4. Stefanini GG, Kalesan B, Serruys PW, Heg D, Buszman P, Linke $A$, et al. Long-term clinical outcomes of biodegradable polymer biolimus-eluting stents versus durable polymer sirolimus-eluting stents in patients with coronary artery disease (LEADERS): 4 year follow-up of a randomized non-inferiority trial. Lancet. 2011;378(9807):1940-8.

5. Carrié D, Berland J, Verheye S, Hauptmann KE, Vrolix M Violini $\mathrm{R}$, et al. A multicenter randomized trial comparing amphilimus - with paclitaxel - eluting stents in the novo native coronary artery lesions. J Am Coll Cardiol. 2012;59(15):1371-6

6. Serruys PW, Ormiston JA, Onuma Y, Regar E, Gonzalo N Garcia-Garcia HM, et al. A bioabsorbale everolimus-eluting coronary stent system (ABSORB): 2-year outcomes and results from multiple imaging methods. Lancet. 2009;373(9667): 897-910.

7. Gray WA, Granada JF. Drug-coated balloons for the prevention of vascular restenosis. Circulation. 2010;121(24):2672-80.

8. McFadden EP, Stabile E, Regar E, Cheneau E, Ong AT, Kinnaird T, et al. Late thrombosis in drug-eluting coronary stents after discontinuation of antiplatelet therapy. Lancet. 2004; 364(9444):1519-21.

9. Serruys PW, Onuma Y, Dudek D, Smits PC, Koolen J, Chevalier B, et al. Evaluation of the second generation of a bioresorbable everolimus-eluting vascular scaffold for the treatment of de novo coronary artery stenosis: 12-month clinical and imaging outcomes. J Am Coll Cardiol. 2011;58(15):1578-88.

10. Habara S, Mitsudo K, Kadota K, Goto T, Fujii S, Yamamoto H, et al. Effectiveness of paclitaxel-eluting balloon catheter in patients with sirolimus-eluting stent restenosis. JACC CardiovasC Interv. 2011;4(2):149-54

11. Murgia MG, Jordan S, Kahan BD. The side effect profile of sirolimus: a phase I study in quiescent cyclosporineprednisonetreated renal transplant patients. Kidney Int. 1996;49(1):209-16.

12. Sousa JE, Costa MA, Abizaid A, Abizaid AS, Feres F, Pinto IM, et al. Lack of neointimal proliferation after implantation of sirolimus-coated stents in human coronary arteries: a quantitative coronary angiography and three-dimensional intravascular ultrasound study. Circulation. 2001;103(2):192-5.

13. Colégio Brasileiro de Experimentação Animal. Princípios éticos na experimentação animal. São Paulo: COBEA; 1991.

14. Takimura CK, Galon MZ, Lopes Junior ACA, Carvalho J, Ferreira SK, Chaves MJF, et al. Avaliação pela tomografia de coerência óptica de stent nacional recoberto com polímero biodegradável eluidor de sirolimus vs. stent eluidor de biolimus A9 em artérias coronárias porcinas. Rev Bras Cardiol Invasiva. 2011;19(2):138-44. 
15. Doshi M, Sherdiwala D, Sojitra P, Vyas A, Gandhi P. Rejuvenating coronary artery by improving blood flow with the help of insertion of nano-balls (encapsulated nanoparticles) containing therapeutic agents by non-implantable medical device for tissues and thereby providing in-tissue release to address the required cell cycle. US 20120065584 A1, Mar 15, 2012.

16. Doshi M, Sherdiwala D, Sojitra P, Vyas A, Gandhi P, Zagabathuni M. Reestablishment of blood flow in blocked human arteries by transferring nano-encapsulated drug through medical devices, designed for the same and releasing the nano-encapsulated drug in human arteries. US 20110264188 A1, Oct 27, 2011

17. Yasdani S, Nakano M, Sherdiwala DP, Prakash S, Kolodgie FD, Virmani R. A temporal assessment of drug distribution following local balloon delivery of nanoparticle sirolimus. J Am Coll Cardiol. 2011;58 Suppl:B6.

18. Lemos PA, Laurindo FRM, Morato SP, Takimura C, Campos CA, Gutierrez PS, et al. Stent coronário de liga cobalto-cromo concebido no Brasil: achados histológicos preliminares em modelo experimental porcino. Rev Bras Cardiol Invasiva. 2007; 15(4):378-85.

19. Kornowski R, Hong MK, Tio FO, Bramwell O, Wu H, Leon MB. In-stent restenosis: contributions of inflammatory responses and arterial injury to neointimal hyperplasia. J Am Coll Cardiol. 1998;31(1):224-30.

20. Suzuki T, Kopia G, Hayashi S, Bailey LR, Llanos G, Wilensky R, et al. Stent-based delivery of sirolimus reduces neointimal formation in a porcine coronary model. Circulation. 2001;104(10):1188-93.

21. Schwartz RS, Edelman ER, Carter A, Chronos N, Rogers C, Robinson KA, et al. Drug-eluting stents in preclinical studies: recommended evaluation from a consensus group. Circulation. 2002;106(14):1867-73.

22. Gunn J, Arnold N, Chan KH, Shepherd L, Cumberland DC, Crossman DC. Coronary artery stretch versus deep injury in the development of in-stent neointima. Heart. 2002;88(4):401-5.
23. Herdeg C, Oberhoff M, Baumbach A, Blattner A, Axel DI, Schröder S, et al. Local paclitaxel delivery for the prevention of restenosis: biological effects and efficacy in vivo. J Am Coll Cardiol. 200;35(7):1969-76.

24. Scheller B, Speck U, Abramjuk C, Bernhardt U, Böhm M, Nickening G. Paclitaxel balloon coating, a novel method for prevention and therapy of restenosis. Circulation. 2004;110(7):810-4.

25. Scheller B, Hehrlein C, Bocksch W, Rutsch W, Haghi D, Dietz $U$, et al. Treatment of coronary in-stent restenosis with a paclitaxel-coated balloon catheter. $N$ Engl J Med. 2006;355(20):2113-24.

26. Zimarino $M$, De Caterina R. Drug-eluting balloons for percutaneous coronary interventions. Thromb Haemost. 2009;101(1):9-11.

27. Wijns W, Kohh P, Danchin N, Di Mario C, Falk V, Folliguet $T$, et al. Guidelines on myocardial revascularization. Task Force on Myocardial Revascularization of the European Society of Cardiology (ESC) and the European Association for CardioThoracic Surgery (EACTS); European Association for Percutaneous Cardiovascular Interventions (EAPCI). Eur Heart J. 2010;31(20):2501-55.

28. Nakano K, Egashira K, Masuda S, Funakoshi K, Zhao G, Kimura $\mathrm{S}$, et al. Formulation of nanoparticle-eluting stents by a cationic electrodeposition coating technology. J Am Coll Cardiol Interv. 2009;2(4):277-83.

29. Schwartz RS, Edelman E, Virmani R, Carter A, Granada J, Kaluza GL, et al. Drug-eluting stents in preclinical studies: updated consensus recommendations for preclinical evaluation. Circ Cardiovasc Interv. 2008;1(2):143-53.

30. Granada JF, Milewski K, Zhao H, Stankus JJ, Tellez A, Abodi MS, et al. Vascular response to zotarolimus-coated balloons in injured superficial femoral arteries of the familial hypercholesterolemic swine. Circ Cardiovasc Interv. 2011;4(5):447-55

31. Cremers B, Toner JL, Schwartz LB, von Oepen R, Speck U, Kaufels $\mathrm{N}$, et al. Inhibition of neointimal hyperplasia with a novel zotarolimus coated balloon catheter. Clin Res Cardiol. 2012;101(5):469-76. 